DOI: http://dx.doi.org/10.18203/2320-1770.ijrcog20184119

Original Research Article

\title{
Caesarean section on demand: a hospital-based study
}

\author{
Mahvish Qazi ${ }^{1}$, Najmus Saqib ${ }^{2 *}$ \\ ${ }^{1}$ Department of Obstetrics and Gynecology, ASCOMS Jammu, Jammu and Kashmir, India \\ ${ }^{2}$ Department of Pediatrics, GMC Jammu, Jammu and Kashmir, India
}

Received: 16 July 2018

Accepted: 28 August 2018

\section{*Correspondence:}

Dr. Najmus Saqib,

E-mail: shstar321@gmail.com

Copyright: (c) the author(s), publisher and licensee Medip Academy. This is an open-access article distributed under the terms of the Creative Commons Attribution Non-Commercial License, which permits unrestricted non-commercial use, distribution, and reproduction in any medium, provided the original work is properly cited.

\begin{abstract}
Background: The aim of the study was to find out the reasons behind healthy women preferring cesarean section (CS) in the absence of obstetric and medical indications.

Methods: This was a prospective study among women who came for delivery at ASCOMS, Jammu (Jammu and Kashmir), India a tertiary level teaching hospital. All women who underwent caesarean delivery for maternal request were included in this study.

Results: The total number of deliveries during the study period (9 months) were 889 . There were $636(71.54 \%)$ vaginal deliveries and $253(28.46 \%)$ CSs. Among 253 CSs, $25(9.88 \%)$ had maternal request as their indication. Majority $13(52 \%)$ of them were in the age group of 20 - 25 years. Multigravida opted for CS more than primigravida (17 versus 8$)$. Most 10 (40\%) of them were Graduates and $15(60 \%)$ were working. Majority of them $13(52 \%)$ were in class II socioeconomic status of Kuppuswamy's scale. The various reasons for women requesting cesarean delivery were refusal of vaginal birth after cesarean section (VBAC), simultaneous tubectomy, painless delivery, prolonged infertility, afraid of neonatal outcome and astrological concerns.

Conclusions: Most of the women who opted for cesarean delivery in our study was for preventable reasons like painless labor, previous negative birth experience and simultaneous tubectomy which would have been avoided by prior counseling starting from antenatal period and by providing labor analgesia. Proper education of the patient and personal involvement of the treating obstetrician in counselling the patient and her supporters can reduce cesarean delivery for maternal request.
\end{abstract}

Keywords: Cesarean delivery, Maternal request, Painless labor

\section{INTRODUCTION}

Cesarean sections (CS) have been a global public health concern for decades. ${ }^{1-3}$ CS rates are increasingly epidemic nearly worldwide. In 1985, the World Health Organization (WHO) recommended that the optimal CS rates should not be higher than $10 \%$ to $15 \%$ and this recommendation has become a reference up to this day. ${ }^{4}$ The levels of 10\%-15\% were considered high but acceptable at the time. However, the average CS rates in the majority of developed regions (with the exception of
Eastern Europe) currently exceed 20\%.5,6 There is no evidence to show any benefit either to mother or to infant when the procedure is not medically indicated. ${ }^{7}$ On the other hand there is high chance of associated short and long term risk which can extend many years beyond the index delivery and affect the health of the woman, her child and future pregnancies. These risks are higher in women with limited access to comprehensive obstetric care. ${ }^{4-6}$ Cesarean delivery on maternal request (CDMR) refers to a primary pre labour $\mathrm{CD}$ performed in the absence of maternal or fetal medical indications. ${ }^{8}$ 
Cause of this increase trend: Some possible reasons those have been reported for this are fear of pain; concerns about genital modifications after vaginal delivery; misconception that CS is safer for the baby, tocophobia, previous poor experiences with labor or concern about specific outcomes including prolapse, anal and urinary incontinence, fetal injury, uncertainty of outcome of a trial, need for emergency cesarean or assisted vaginal delivery and convenience for the mother and family.

Some cultural factors also have been found. For example, in China choosing the date of the baby's delivery on the basis of luck and fate for the future of the baby by some people is one of the explanations for scheduling a CS. ${ }^{9}$ Some women even believe that a baby delivered by cesarean section may be cleverer because the baby was not squeezed in the birth canal. ${ }^{10-12}$

Table 1: Summary of consensus recommendations or statements on caesarean delivery on maternal request.

\begin{tabular}{|c|c|}
\hline Organisation & Recommendations \\
\hline $\begin{array}{l}\text { American } \\
\text { College of } \\
\text { Obstetricians } \\
\text { and } \\
\text { Gynecologists }^{8}\end{array}$ & $\begin{array}{l}\text { Recommendations in cases in } \\
\text { which CDMR is planned: } \\
\text { - CDMR should not be } \\
\text { performed before } 39 \text { weeks. } \\
\text { CDMR should not be } \\
\text { motivated by the unavailability } \\
\text { of effective pain management. } \\
\text { CDMR particularly is not } \\
\text { recommended for women } \\
\text { desiring several children given } \\
\text { that each CD increases the risk } \\
\text { of placenta praevia, placenta } \\
\text { accrete and hysterectomy. }\end{array}$ \\
\hline $\begin{array}{l}\text { Royal } \\
\text { Australian and } \\
\text { New Zealand } \\
\text { College of } \\
\text { Obstetricians } \\
\text { and } \\
\text { Gynecologists }^{13}\end{array}$ & $\begin{array}{l}\text { If, after full discussion, the patient } \\
\text { maintains CDMR, the obstetrician } \\
\text { may: } \\
\text { - Agree to perform CD if patient } \\
\text { understands risks and benefits } \\
\text { of this course of action. } \\
\text { Decline to perform CD if } \\
\text { obstetrician believes there are } \\
\text { significant health concerns for } \\
\text { mother or baby; or patient } \\
\text { appears to not have sufficient } \\
\text { understanding to enable } \\
\text { informed consent. }\end{array}$ \\
\hline $\begin{array}{l}\text { National } \\
\text { Institute for } \\
\text { Health and } \\
\text { Care } \\
\text { Excellence }^{14}\end{array}$ & $\begin{array}{l}\text { If a woman requests a CD: } \\
\text { - Discuss and record reasons for } \\
\text { request. } \\
\text { - Discuss and record overall } \\
\text { risks and benefits of CD } \\
\text { compared with vaginal birth. } \\
\text { - Discuss request with other } \\
\text { members of obstetrics team to } \\
\text { ensure woman has accurate } \\
\text { information. }\end{array}$ \\
\hline
\end{tabular}

\section{METHODS}

Authors performed a prospective study in women who came for delivery at ASCOMS, Jammu (Jammu and Kashmir), India a tertiary level teaching hospital.

\section{Inclusion criteria}

- All women who underwent CS on demand/ maternal request, both primigravida and multigravida, were included.

\section{Exclusion criteria}

- CS performed for any obstetric or medical indications like contracted pelvis, cephalo pelvic disproportion, malpresentations, placenta previa, fetal distress, etc.

Total study period was from October 2017 to June 2018 (9 months). Totally 25 women were included in this study. Among 25 women, 8 were primigravida and 17 were multigravida. The age of each woman, her education, occupation, parity and previous mode of delivery were recorded. Women who opted for cesarean delivery were put through a questionnaire enquiring about the reason for opting cesarean delivery, the reason for not undergoing vaginal delivery, the merits and demerits of both vaginal delivery and cesarean delivery that they know about and any family member or friend who had influenced her regarding the mode of delivery. All the data were analyzed. The total duration of hospital stay, development of maternal and perinatal complications if any, were also analyzed.

\section{RESULTS}

In this prospective study, a total of 25 women were included. Majority $13(52 \%)$ of them were in the age group of 20-25 years. Multigravida opted for CS more than primigravida (17 versus 8$)$. All were in term gestation when they underwent CS. Most 10 (40\%) of them were Graduate and $15(60 \%)$ were working. Majority of them $13(52 \%)$ were in class II socioeconomic status of Kuppuswamy's scale. Table 2 shows demographic data of all the patients studied and Table 3 shows details of previous delivery. Among the multigravida who underwent $\mathrm{CS}$ for maternal request in the study group, $11(44 \%)$ had previous CS and the rest 6 $(24 \%)$ had prior vaginal delivery.

Among primi-gravidae 8 underwent CDMR. Out of these, $4(50 \%)$ underwent CS because they wanted painless delivery, $2(25 \%)$ due to fear of vaginal delivery yet another $2(25 \%)$ women were cases of prolonged infertility saying that they did not want to take risk. Among the multi-gravidae who underwent CDMR. 2 $(11.76 \%)$ women underwent LSCS due painless delivery, $5(29.41 \%)$ of them had an earlier Cesarean section because of prolonged infertility and wanted an elective 
repeat Cesarean section, $2(11.76 \%)$ more women refused VBAC for fear of complications .1 (5.89\%) of them when explained regarding trial of labor opted for caesarean delivery due to previous traumatic delivery. 1 (5.89\%) woman who delivered vaginally before had bad obstetric history and she lost her child in the neonatal period.

Table 2: Demographic analysis of patients studied.

\begin{tabular}{|c|c|c|}
\hline Variables & No. of patients & Percentage \\
\hline \multicolumn{3}{|l|}{ Age in years } \\
\hline$<20$ & 2 & 8 \\
\hline $20-25$ & 13 & 52 \\
\hline $26-30$ & 7 & 28 \\
\hline $31-35$ & 2 & 8 \\
\hline$>35$ & 1 & 4 \\
\hline \multicolumn{3}{|l|}{ Parity } \\
\hline Primigravida & 8 & 32 \\
\hline Multigravida & 17 & 68 \\
\hline \multicolumn{3}{|c|}{ Period of gestation (weeks) } \\
\hline $38-39$ & 13 & 52 \\
\hline $39-40$ & 11 & 44 \\
\hline$>40$ & 1 & 4 \\
\hline \multicolumn{3}{|c|}{ Patient education } \\
\hline Illiterate & 2 & 8 \\
\hline Primary school & 5 & 20 \\
\hline Middle school & 2 & 8 \\
\hline High school & 6 & 24 \\
\hline Graduate & 10 & 40 \\
\hline \multicolumn{3}{|c|}{ Socioeconomic status } \\
\hline Class I & 0 & 0 \\
\hline Class II & 13 & 52 \\
\hline Class III & 7 & 28 \\
\hline Class IV & 1 & 4 \\
\hline Class V & 4 & 16 \\
\hline \multicolumn{3}{|l|}{ Occupation } \\
\hline Working & 15 & 60 \\
\hline
\end{tabular}

Table 3: Details of previous delivery and indications for prior cesarean delivery.

\begin{tabular}{|l|l|l|}
\hline Mode of delivery & No. of patients & Percentage \\
\hline Vaginal delivery & 6 & 24 \\
\hline Cesarean delivery & 11 & 44 \\
\hline \multicolumn{2}{l|}{ Indications for prior cesarean delivery } & \\
\hline Oligohydramnios & 3 & 12 \\
\hline Fetal distress & 3 & 12 \\
\hline Breech presentation & 2 & 8 \\
\hline PROM & 2 & 8 \\
\hline Placenta previa & 1 & 4 \\
\hline
\end{tabular}

The details were not known. 2 (11.76\%) women underwent LSCS due to fear of vaginal delivery, 3 $(17.64 \%)$ women with prior vaginal delivery who were not ready to tolerate the pain again and they also wanted concomitant sterilization along with CS provided the baby's condition was satisfactory. 1 (5.89\%) women insisted for cesarean because they wanted baby extraction at a particular time due to astrological concerns. Table 4 briefs the various reasons for cesarean delivery on maternal request.

Table 4: Reason for caesarean delivery on maternal request.

\begin{tabular}{|lll|}
\hline Indication & $\begin{array}{l}\text { No. of } \\
\text { primi- } \\
\text { gravidae } \\
(\mathrm{N}=8)\end{array}$ & $\begin{array}{l}\text { No. of } \\
\text { multi- } \\
\text { gravidae } \\
(\mathrm{N}=17)\end{array}$ \\
\hline Painless delivery & $4(50 \%)$ & $2(11.76 \%)$ \\
\hline Previous cesarean section & - & $5(29.41 \%)$ \\
\hline Refusal of VBAC & - & $2(11.76 \%)$ \\
\hline Previous traumatic delivery & - & $1(5.89 \%)$ \\
\hline Previous intrapartum death & - & $1(5.89 \%)$ \\
\hline Fear of vaginal delivery & $2(25 \%)$ & $2(11.76 \%)$ \\
\hline Concomitant sterilization & - & $3(17.64 \%)$ \\
\hline $\begin{array}{l}\text { Prolonged infertility and } \\
\text { treatment conception }\end{array}$ & $2(25 \%)$ & - \\
\hline Astrological reasons & - & $1(5.89 \%)$ \\
\hline
\end{tabular}

Complications found during the study are shown in Table 5. There were no maternal complications during the study period. One child had MAS was put on Continuous Positive Airway Pressure (CPAP) for 1 day and on oxygen for 2 days later recovered.

Table 5: Complications.

\begin{tabular}{|lll|}
\hline $\begin{array}{l}\text { Complication } \\
\text { Meconium aspiration }\end{array}$ & No. of patients & Percentage \\
syndrome (MAS) & 1 & 4 \\
\hline
\end{tabular}

\section{DISCUSSION}

Women's requests for caesarean sections in the absence of clear biological risks may seem irrational. However, traumatic birthing experiences often result from an antagonistic relationship with healthcare providers and a poor hospital environment-two aspects that are particularly acute for women who feel marginalized from society. The doctor-patient relationship is complex and private, requiring mutual respect and trust. The patient's right to refuse or limit treatment is well tested and universally acknowledged, but the opposite right to request certain interventions, while perfectly acceptable in many situations seems to have caused significant controversy with respect to CS. ${ }^{15}$ The total number of deliveries during the study period ( 9 months) were 889 . There were $636(71.54 \%)$ vaginal deliveries and 253 (28.46\%) CSs. The CS rate is high (28.46\%).as present hospital is a tertiary rural referral center, receiving many patients who are handled outside and get admitted with features of obstructed labor and fetal distress.

Among 253 cesarean deliveries, 25 (9.88\%) had maternal request as their indication. Estimates of caesarean delivery on maternal request range from 4-18 percent but there is little confidence in the validity of these estimates as CDMR is not a well-recognised clinical entity and 
there are currently no accurate means of reporting it. ${ }^{16,17}$ In present study, multigravida $17(68 \%)$ opted for CS more than primigravida $8(32 \%)$ based on their experience with previous child birth. Among 11 (44\%) multigravida, who had undergone primary CS for nonrecurrent indications like oligohydramnios, fetal distress and placenta previa were comfortable about the previous CS as they did not have any complications and refused to undergo trial of vaginal delivery. In present study, majority were graduate $10(40 \%), 6(24 \%)$ studied up to high school, 15 (60\%) were employed and majority 13 $(52 \%)$ were from class II socioeconomic status. This is in consistent to a study by Behague et al who found that CSs were more common among wealthy, educated women and those with more antenatal attendance. ${ }^{18}$

The reason for opting for cesarean delivery should be determined and addressed. Anxiety and fear arising from personal trauma, previous childbirth experiences, should be addressed. Tocophobia may be tackled by providing information about obstetric analgesia and anesthesia as well as consultation with an anesthesiologist. Currently, International Federation of Gynecology and Obstetrics (FIGO), World Health Organization (WHO) and the Society of Obstetricians and Gynecologists of Canada do not support CDMR. ${ }^{19}$ The reasons cited are the lack of evidence demonstrating that in a normal low risk pregnancy CS carries less risk than vaginal delivery for mother and baby and the attendant increased use of health resources. ${ }^{20}$ The most meaningful comparisons of morbidity need to be between those women having an elective CS and those undergoing labor. No such studies have been done in fit healthy women with no medical indication for $\mathrm{CS}^{21}$

The implications for future child bearing are the most relevant long-term consequences of CS. The incidences of placenta praevia and placenta accreta increase almost linearly after each CS as Silver et al found that placenta accreta was present in $0.24 \%, 0.31 \%, 0.57 \%, 2.1 \%, 2.3 \%$ and $6.7 \%$ of women undergoing their first, second, third, fourth, fifth, and sixth or more caesarean deliveries, respectively. ${ }^{22} \mathrm{CD}$ may be associated in subsequent pregnancies with delayed conception, increased risk of ectopic pregnancy, possibly intrauterine growth restriction (IUGR), pre-term birth, unexplained stillbirth after 34 weeks and uterine scar dehiscence or rupture. ${ }^{23}$ Finally and given the current level of knowledge, one cannot certify the superiority of a delivery route over another as regards to pain after delivery, pelvic pain, postpartum depression, fistulas and maternal mortality. ${ }^{8}$

\section{CONCLUSION}

The proliferating increased rates of caesarean section have not only affected the developed countries but also expanded to developing countries like India. A lot of risks both immediate and remote have been associated with caesarean section but is largely unknown to the population experiencing the process. Health education especially antenatal education regarding safety of vaginal delivery and the cons of caesarean section would be a valuable tool to be offered at population level. Late intrauterine fetal demises may not be reduced by a policy of universal elective cesarean section. Caesarean section itself carries a risk of iatrogenic prematurity, morbidity and mortality. Management of labor should be individualized so as to facilitate women to have vaginal deliveries.

\section{ACKNOWLEDGMENTS}

Author want to thank all subjects who participated and cooperated for the study.

\section{Funding: No funding sources}

Conflict of interest: None declared

Ethical approval: The study was approved by the Institutional Ethics Committee

\section{REFERENCES}

1. Victora CG, Barros FC. Beware: unnecessary caesarean sections may be hazardous. Lancet. 2006;367(9525):1796-7.

2. Villar J, Carroli G, Zavaleta N, Donner A, Wojdyla $\mathrm{D}$, Faundes A, et al. Maternal and neonatal individual risks and benefits associated with caesarean delivery: multicentre prospective study. BMJ. 2007;335(7628):1025.

3. WHO, UNFPA, UNICEF, AMDD. Monitoring emergency obstetric care a handbook. Geneva, Switzerland: World Health Organization; 2009. Available http://whqlibdoc.who.int/publications/2009/9789241 547734_eng.pdf.

4. Zahr CA, Wardlaw TM, Choi Y. Maternal mortality in 2000: estimates developed by WHO, UNICEF and UNFPA. World Health Organization; 2004.

5. MacKenzie IZ. Should women who elect to have caesarean sections pay for them?. BMJ: British Med J. 1999;318(7190):1070.

6. Lauer JA, Betrán AP, Merialdi M, Wojdyla D. Determinants of caesarean section rates in developed countries: supply, demand and opportunities for control. World Health Report. 2010;29.

7. Hannah ME, Hannah WJ, Hewson SA, Hodnett ED, Saigal S, Willan AR, et al. Planned caesarean section versus planned vaginal birth for breech presentation at term: a randomised multicentre trial. Lancet. 2000;356(9239):1375-83.

8. American College of Obstetricians and Gynecologists. ACOG committee opinion no. 559: cesarean delivery on maternal request. Obstet Gynecol. 2013;121(4):904-7.

9. Mi J, Liu F. Rate of caesarean section is alarming in China. Lancet. 2014;383(9927):1463-4.

10. Ouyang YQ, Zhang Q. A study on personal mode of delivery among Chinese obstetrician-gynecologists, 
midwives and nurses. Arch Gynecol Obstet. 2013;287(1):37-41.

11. Harris A, Gao Y, Barclay L, Belton S, Yue ZW, Min $\mathrm{H}$, et al. Consequences of birth policies and practices in post-reform China. Reprod Health Matters. 2007; 15(30):114-24.

12. Lee LY, Holroyd E, Ng CY. Exploring factors influencing Chinese women's decision to have elective caesarean surgery. Midwifery. 2001;17(4):314-22.

13. The Royal Australian and New Zealand College of Obstetricians and Gynaecologists. Caesarean Delivery on Maternal Request (CDMR). C-Obs 39. Melbourne VIC: RANZCOG; 2013. Available at: www.ranzcog.edu.au/college-statementsguidelines.html.

14. National Institute for Health and Care Excellence. Caesarean Section. CG132. London: NICE; 2011. Available at: http://www.nice.org.uk/guidance/CG132/ chapter/Woman-centred-care.

15. Paterson-Brown S, Fisk NM. Caesarean section: every woman's right to choose? Curr Opin Obstet Gynecol. 1997;9(6):351-5.

16. National Institutes of Health. State-of-the-science conference statement: Cesarean delivery on maternal request. Obstet Gynecol. 2006;107:1386-97.

17. Agency for Healthcare Research and Quality. Evidence report/technology assessment No. 133: Cesarean delivery on maternal request, 2006.
18. Behague DP, Victora CG, Barros FC. Consumer demand for caesarean sections in Brazil: informed decision making, patient choice, or social inequality? A population-based birth cohort study linking ethnographic and epidemiological methods. BMJ. 2002;324(7343):942-5.

19. Pakenham S, Chamberlain SM, Smith GN. Women's views on elective primary caesarean section. J Obstet Gynaecol Can. 2006;28(12):1089-94.

20. Society of Obstetricians and Gynecologists of Canada, Advisory. C-Sections on Demand-SOGC's Position, March 10, 2004. Available at: http://www.sogc.org.

21. Mcmahon MJ, Luther ER, Bowes WA, Olshan AF. Comparison of a trial of labor with an elective second caesarean section. New England J Med. 1996;75:912-6.

22. Silver RM, Landon MB, Rouse DJ, Leveno KJ, Spong CY, Thom EA, et al. Maternal morbidity associated with multiple repeat cesarean deliveries. Obstet Gynecol. 2006;107(6):1226-32.

23. D'Souza R, Arulkumaran S. To 'C' or not to 'C'? Caesarean delivery upon maternal request: a review of facts, figures and guidelines. J Perinat Med. 2013;41(1):5-15.

Cite this article as: Qazi M, Saqib N. Caesarean section on demand: a hospital-based study. Int J Reprod Contracept Obstet Gynecol 2018;7:4003-7. 